\title{
NÖROLEPTIK MALIGN SENDROMDA HEMŞIRELIK BAKIMI: OLGU SUNUMU
}

\author{
Yasemin ÇEKIÇ ${ }^{1}$, Yeşim SAYMAZ ${ }^{2}$
}

\begin{abstract}
ÖZET
Nöroleptik malign sendrom, ender görülmesine karşın mortalite riski yüksek olan bir sendrom olması sebebiyle erken tanınması, etkili biçimde tedavi edilmesi gereken önemli bir sağlık problemidir. Tedavinin yanı sıra etkin bir hemşirelik bakımı verilmesi, hasta ve yakınlarının önceki dengelerine dönmelerinde yaşamsal öneme sahiptir. Bu olguda, atipik antipsikotik (paliperidol) ile birlikte lityum ilacı kullanımına bağlı nöroleptik malign sendrom gelişen bipolar bozukluk tanılı hastanın sağaltımını sağlayan hemşirelik bakımı anlatılmıştır.
\end{abstract}

Anahtar sözcükler: nöroleptik malign sendrom, hemşirelik, bakım, olgu

\section{Nursing Care for Neuroleptic Malignant Syndrome: Case Report}

\section{Abstract}

Neuroleptic malignant syndrome is a significant health problem that should be diagnosed at the early stages and treated effectively due to its high mortality risk, although it is seldom seen. In addition to treatment, providing effective nursing care to patients and their relatives to ensure their life balance is critical. This case deals with the nursing care used to treat a patient diagnosed with bipolar disorder and neuroleptic malignant syndrome because of using lithium drug with an atypical antipsychotic (paliperidol).

Keywords: care, case report, neuroleptic malignant syndrome, nursing.

1 Arş. Gör., Aktaş Mah. Plevne Cad. No: 5 Altındağ/ANKARA, yasemin05@msn.com, 05447719997 (iletişim yazarı)

2 Ankara Üniversitesi Tıp Fakültesi Ruh Sağığı ve Hastalıkları Anabilim Dalı Cebeci/ANKARA, yesimsaymaz@hotmail.com, 05063566738 


\section{GiRiş}

Nöroleptik malign sendrom (NMS), nöroleptik kullanımı sonucu hastalarda \%0,1-2,5 oranında görülen, ancak yaşamsal önemi olan ağır, tehlikeli bir bozukluktur ve ölüm oranı \%4-55 arasında değişmektedir. ${ }^{1,2}$ Ölümler akut böbrek yetmezliği, akut solunum yetmezliği, aspirasyon, şok, pulmoner emboli, myokard enfaktüsü ve sepsis gibi komplikasyonlar sonucu gerçekleşmektedir. ${ }^{3}$ NMS görülme riski ilaç kullanımını takiben ilk 10 gün yüksek olmasına rağmen, ilaç dozu ve süresine bakılmaksızın tedavinin herhangi bir aşamasında ortaya çıkabilmektedir. ${ }^{4}$

NMS' de yüksek ateş, kas rijiditesi ve kreatin fosfokinaz (CPK) yüksekliği olmak üzere üç temel belirti görülür. ${ }^{5}$ Bunların yanı sıra karaciğer enzimlerinde yükselme, konfüzyondan deliryuma kadar değişebilen bilinç bulanıklığı, şiddetli terleme, tremor, inkontinans, kan basıncı değişiklikleri ve taşikardi ortaya çıkabilmektedir. $5,6,7$

Belirtiler yönünden birçok tıbbi tablo ile karıştırılabilen NMS' de belirtileri erken fark etme, ayrımını yapma ve tedavi sürecinde etkin bir hemşirelik bakımı verme büyük öneme sahiptir. Hemşirelerin NMS' de sorumlulukları; NMS gelişiminin önlenmesi ve belirtileri erken tanıma, NMS gelişti ise etkili hemşirelik bakımı verme, komplikasyonların önlenmesi, taburculuk eğitimi, hasta ve ailenin bilgilendirilmesi ve önceki dengelerine dönmelerinin sağlanması olarak özetlenebilir. ${ }^{8}$ NMS ile ilgili yayınlanan olgulara bakıldığında tıbbi tedavi ve hemşirelik bakımına ilişkin ayrı ayrı çalışmalar bulunmakta ancak bir olgunun hemşirelik bakımına rastlanmamaktadır. Bu nedenle bu yazıda bir olgunun hemşirelik bakımı uygulamaları aktarılarak hemşirelere bakım kalitesini artırmada rehberlik edileceği düşünülmektedir.

\section{Olgu}

Yirmiüç yaşında olan kadın hasta işitsel varsanı, psikomotor aktivitede artış, uyku intiyacında azalma ve saldırgan davranışlar gösterme şikayetleri ile psikiyatri kliniğine başvurdu. Bipolar bozukluk tanısı ile psikiyatri kliniğine yatırılan hastaya Paliperidon $6 \mathrm{mg} / \mathrm{gün}$, Biperidon 4mg/gün, Lityum $600 \mathrm{mg} / \mathrm{gün}$ başlandı. Hatanın ilaç tedavisi başlamadan önceki laboratuar bulguları: lökosit (WBC): 8400 $\mathrm{k} / \mathrm{\mu l}$, aspartat amino transferaz (AST):15 U/L, alanin amino transferaz (ALT):19 U/L, CPK: $47 \mathrm{UL}$ olarak belirlendi. Yaşam bulguları; kan basıncı: $100170 \mathrm{mmHg}$, nabız: $801 \mathrm{dk}$, ateş:36,2 ${ }^{\circ} \mathrm{C}$ idi. İlaç uyumu iyi 
olan hastanın izleminin 16. gününde, dengesini sağlamakta güçlük çekmesi ve düşerek kafasını çarpması üzerine kranial bilgisayarlı tomografi (BT)' si çekildi. BT sonucunda hastanın nörolojik bir sıkıntısının olmadığı saptandı. Ancak ilerleyen günlerde dengesi tamamen bozulan, konfüzyonu artan, bilinci stupor düzeyine gerileyen ve iletişimi tamamen kopan hastanın aşırı terlediği, bulantı, kusma ve kas rijiditesinde artış olduğu gözlendi. NMS' den şüphe edilen hastanın yaşam bulguları hemşire tarafından sık sık takip edildi. Hastanın fiziksel muayenesi, rutin kan tetkiklerinin yapılmasının ardından uygulanan ilaç tedavisi sonucu laboratuar bulgularının WBC: $13000 \mathrm{k} / \mu \mathrm{l}$, AST: $59 \mathrm{U} / \mathrm{L}$, ALT: $60 \mathrm{U} / \mathrm{L}, \mathrm{CPK}: 1849 \mathrm{UL}$ olarak değiştiği belirlendi. Yaşam bulguları: kan basıncı: $140190 \mathrm{mmHg}$, nabız: $130 \mathrm{ldk}$, ateş: $38,8^{\circ} \mathrm{C}$ olarak saptandı. Bilinen tıbbi başka bir hastalığı olmayan hastanın NMS ön tanısı ile tıbbi tedavisi ve hemşirelik bakımı uygulandı. NMS tanısı konur konmaz hastanın kullanmakta olduğu Biperidon, Paliperidon ve Lityum ilaç tedavileri kesilip yerine Bromokriptin 15mg/gün, Volproat $1000 \mathrm{mg} / g u ̈ n ~ o l a r a k$ tedavisi yeniden düzenlendi. Uygulanan tıbbi tedavi ve uygun hemşirelik bakımı sonucu, 20 gün sonra hastanın durumu stabil hale geldi.

\section{Hemşirelik Bakımı}

Kuzey Amerika Hemşireler Birliği (NANDA) ${ }^{9}$ tarafından 1973 yılında geliştirilen "hemşirelik tanıları" doğrultusunda olguya aşağıdaki hemşirelik tanıları, hedefler, girişimler ve gerekçeleri doğrultusunda hemşirelik bakımı uygulanmıştır:

1) Hemşirelik tanısı: Aktivite intoleransı

Veriler: Konfüzyon

Hedefler: Artan aktiviteyi tolere edebilme, günlük yaşam aktivitelerini yapabilme.

\section{Hemşirelik Girişimleri:}

- Hastanın yaşam bulguları, katatoni gelişip gelişmediği, hareket mesafesi, süresi, gücü ve kapasitesi, kas rijiditesi izlenerek değerlendirildi.

- Öncelikli hareket gereksinimleri belirlendi ve hareketi için destek sağlandı. 
- Hasta yatakta hareketli tutuldu, aktif-pasif hareketler yaptırıldı, mümkün olan en erken sürede hareket etmesi sağlandı ve kendi bakımına katılımı için hasta cesaretlendirildi.

- Hastanın yeterince uyuması ve dinlenmesi sağlandı.

2) Hemşirelik tanısı: Vücut ısısını düzenlemede yetersizlik (Hipertermi)

Veriler: Vücut ısısının normalden yüksek olması $\left(38.8{ }^{\circ} \mathrm{C}\right)$, taşikardi (130/dk), titreme.

Hedefler: Vücut ısı sının normal sınırlarda seyretmesi.

Hemşirelik Girişimleri:

- Vücut Isısı, diğer yaşam bulguları ve mental değişiklikler sık aralıklarla izlendi.

- Hastanın vücut ısısını düşürmek için periferik soğuk uygulama yapıldı.

- Hastanın yeterli miktarda sıvı alması sağlandı.

- Terlemesi nedeniyle cilt bakımı yapıldı, cildin kuru kalması sağlandı, teri emen giysiler giydirildi ve uygun oda ısısı sağlandı.

3) Hemşirelik tanısı: Sözel iletişimde bozulma

Veriler: Sözcükleri telaffuz edememe, sözcükleri anımsayamama, anlamlı cümle kuramama, konuşmaların anlamını algılayamama ve yorumlayamama

Hedefler: Hastanın verilen mesajları alması, anlaşılır bir biçimde ifade etmesi ve tepki vermesi.

\section{Hemşirelik Girişimleri:}

- İletişim için zaman ayrıldı, hastanın kendini ifade etmesi desteklendi.

- Anlamadığında sözcükler tekrarlandı, tekrarlama aynı sözcüklerle yapıldı.

- Sözlü iletişim sözsüz iletişimle desteklendi. 
- Hastanın yaşadığı anksiyete ve korkunun nedeni ve düzeyi belirlendi.

- Hastalığın gidişatı hakkında bilgi verilerek belirsizlikler giderildi.

- Yapılan her işlem hastaya açıklandı.

4) Hemşirelik tanısı: Akut konfüzyon

Veriler: Dikkat, algılama, oryantasyon ve düşünmede bozulma, ajitasyon.

Hedefler: Hastanın kendine ve çevresine zarar vermemesi, dikkat ve uyaranlara ilgisinin artması, öz-bakımına katılabilmesi, oryantasyonun sağlanması.

\section{Hemşirelik Girişimleri:}

- Aynı çalışma gününde aynı hemşirenin bakım vermesi ve bunun diğer günlerde de sürdürülmesi sağlandı.

- Hastanın annesinin yanında kalmasına izin verildi. Sevdiği oyuncağı yanına getirildi.

- Düşme ve travma önlendi. Yatak kenarları kaldırıldı, yataktan kalkacağı zaman hastaya yardım edildi, sık kullandığı eşyaları yakınına getirildi.

- Hastanın bilişsel fonksiyonları, yer, zaman, kişi oryantasyonu değerlendirildi. Özellikle sabahları ve vardiya değişimlerinde hasta düzenli olarak oryante edildi. Odasına takvim ve saat yerleştirilip uyarıcı bir çevre oluşturuldu.

- Açık, anlaşılır, kısa, basit cümlelerle, yavaş bir biçimde ve göz teması kurularak konuşuldu.

- Hastaya soru sorarken kapalı uçlu ve tek seçenekli sorular kullanıldı (ne içmek istersin yerine, su ister misin gibi...)

- Konfüzyonu arttırıcı, gürültü, karanlık v.b. çevresel uyaranlar kontrol altına alındı.

- Hasta ve ailesine duruma yönelik düzenli bilgi verildi. Bu durumun geçici olduğu açıklandı. Ailenin hastayla düzenli olarak ilişki kurması sağlandı. 
5) Hemşirelik tanısı: Bireysel bakımda yetersizlik

Veriler: Yemeği ağzına götürememe, yatağa bağımlı halde olma, giysilerine ulaşamama ve kendi başına giyinememe, tuvalete gidememe ve tuvalet sonrası temizliğini yapamama.

Hedefler: Günlük yaşam aktivitelerinin sağlık düzeyini koruyup geliştirecek şekilde karşılanması.

\section{Hemşirelik Girişimleri:}

- Vücut hijyeni sağlandı. El yüz, ağız bakımı, yatak banyosu yaptırıldı. Uygun ve sağlıklı giyinmesi sağlandı.

- Başlangıçta oral alamayan hastanın durumundaki iyileşmeyle paralel olarak yeterli ve dengeli biçimde beslenmesi sağlandı.

- Uygun aralıklarla, düzenli olarak boşaltımı ve perine hijyeni sağlandı.

- Tolere edebildiği ölçüde öz bakımı için yapabileceği aktivitelere katılımı sağlandı.

5) Hemşirelik tanısı: Sıvı volümünde yetersizlik riski

Veriler: Oral sıvı alamama, aşırı terleme.

Hedefler: Metabolik gereksinimlerin karşılayacak ölçüde ve yaşına uygun miktarda sıvı alması.

\section{Hemşirelik Girişimleri:}

- Sıvı kaybına neden olan faktörlere yönelik gerekli girişimler uygulandı (Aşırı terleme vb).

- Günlük aldığı-çıkardığı sıvı takibi yapıldı, yeterli sıvı alması sağlandı, oral alımı yeterli olmayan hastaya hekim istemine uygun intravenöz SIVı verildi.

- Günlük kilo kontrolü yapıldı.

- Dehidratasyon belirtileri ve deri turgoru izlendi.

- Terlemeyi önlemek için uygun giysi ve uygun oda ısısı sağlandı. 
5) Hemşirelik tanısı: Hasta ve ailede bilgi eksikliği

Veriler: Korku ve endişe belirtileri gösterme, hastanın durumundaki ani değişim nedeniyle şaşkınlık

Hedefler: Hasta ve ailenin hastanın sağlık durumu, tedavi ve bakımını doğru olarak anladığını sözel olarak ifade etmesi ve uygun sorular sorması.

\section{Hemşirelik Girişimleri:}

- Ailenin korkuları, hastanın klinik durumunu nasıl algıladıkları belirlendi.

- Aile hastanın güncel sağlık durumu, tedaviler ve prognoza ilişkin sık aralıklarla bilgilendirildi.

- Hastaya yapılan açıklamalarda anlama düzeyine uygun olarak yazılı araçlar kullanıldı.

- Yanlış anlamaya neden olan etkenleri belirlemek ve doğru öğrenmelerini sağlamak amacıyla sık aralıklarla edindikleri bilgileri anlayıp anlamadıkları değerlendirildi.

- Aile bilgi alma, duygularını, endişelerini ve sorularını ifade etmeleri için desteklendi.

\section{Sonuç}

NMS' de sağlık ekibinin ilk görevi NMS gelişmesini önlemek olmakla birlikte eğer bireyde NMS gelişti ise, hastane öncesi acilde, hastanede ve taburculuk sonrasında hastayı etkin bir biçimde ele alma yaşam kurtarıcıdır. Bu süreçte 24 saat hasta ile birlikte vakit geçiren hemşireler, ikincil ve üçüncül komplikasyonları önleme ve dolayısıyla mortaliteyi de azaltma açısından tedavi sürecinde verecekleri uygun hemşirelik bakımı ile hasta ve yakınlarının önceki dengelerine dönmelerinde önemli role sahiptirler.

Olguya verilen etkin hemşirelik bakımı ve tüm sağlık ekibinin de bu bakımın içeriğini bilmesi ekip çalışmasının kalitesini artıran önemli bir noktaydı. Bu olguda hasta ve ailesi NMS'nin tekrar gelişmesini önlemek, eski rol ve işlevlerine yeniden dönebilmek ve olabilecek en üst düzeyde işlev göstermelerini sağlamak amacıyla eğitim verilerek taburcu edildi. Bakıma hastanın ailesi dahil ederek durum bütüncül olarak değerlendirildi. Bu süreçte hastasını fiziksel olarak "sağlam" bir 
şekilde hastaneye yatıran ailenin NMS ortaya çıktıktan sonra yaşadıkları olumsuz duygular, şaşkınlık ve belirsizlik durumunda hemşireler, hasta ve ailenin tedavi ve bakıma uyum sağlamasında, işbirliği yapmasında ve yaşadıkları olumsuz durumla etkin bir biçimde baş etmelerinde anahtar role sahipti. Hasta ve yakınlarının birlikte eğitime alınması, NMS için riskli durumlar ve erken belirtilerin öğretilmesi ve taburculuk sonrası ekip desteğinin devam edeceği bilgisinin verilmesi, belirtileri ilk fark ettiklerinde işbirliği yapmalarının öneminin vurgulanması hasta ve ailenin baş etme güçlerini ve güvenlerini arttırması açısından önemliydi. Etiyolojiye uygun olarak belirlenen hemşirelik tanıları doğrultusunda uygulanan hemşirelik bakımı sonucunda hastada herhangi bir komplikasyon gelişmemesi, hastanın NMS öncesi dengesine dönmesi NMS' de hemşirelik bakımının önemini vurgulamak açısından anlamlıydı

\section{KAYNAKLAR}

1. Kaplan HI, Sadock BJ. Schizophrenia. In: Synopsis of Psychiatry. (8th Edition). Baltimore: William \& Wilkins, 1998; 456-492.

2. Tural U, Önder E. Clinical and pharmacologic risk factors for neuroleptic malignant syndrome and their association with death. Psychiatry and Clinical Neurosciences 2010; 64(1): 79-87.

3. Öztürk MO, Uluşahin A. Ruh Sağlığı ve Bozuklukları. Yenilenmiş 11. baskı. Ankara: Bayt Ltd.Şti, 2008; 848.

4. İspir $M$, Tütüncü $R$, Balıbey $H$, Algül $A$, Ateş $M A$, Yılan $Y$, Öge $C$, Başoğlu C. Bipolar bozukluklu bir hastada paliperidon palmitat ve lityum ile ilişkili nöroleptik malign sendrom: Bir olgu sunumu. Journal of Mood Disorders (JMOOD) 2016; 6(4): 227-9.

5. Öncü $F$, Hariri $A$, Ceylan ME. Nöroleptik malign sendrom. Düşünen Adam, 1998; 11(4): 30-35.

6. Özgüven HD. Ruh Sağlığı ve Hastalıkları. Ankara: Ankara Üniversitesi Basım Evi, 2014; 322.

7. Yiğit H, Mutu T, Örsel ES, Erol A. Haloperidol depo ile gelişen bir nöroleptik malign sendrom olgusu. Journal of Psychiatry 2016; 17(3): 11-13.

8. Ançel G. Nöroleptik malign sendromda hemşire bakımı. Düşünen Adam 2006; 19(1):40-49.

9. Ulaşım adresi: http://www.nanda.org/nanda-international-history-197379.html (Ulaşım Tarihi: 05.05.2017). 